\title{
PEMBINAAN WARGA GEREJA DEWASA MENURUT SURAT EFESUS 4:11-16
}

\author{
Jeny Marlin
}

\section{PENDAHULUAN}

Pada hakikatnya, Gereja adalah ciptaan dan milik Allah (1 Kor. 6:19-20) untuk mempermuliakan-Nya. ${ }^{1}$ Hal ini menunjukkan bahwa, kehadiran Gereja di tengahtengah dunia ini bukan tanpa tujuan, melainkan Allah memiliki visi atau tujuan yang khusus. Berkenaan dengan arti kata Gereja, Louis Berkhof menuliskan bahwa dalam Perjanjian Baru, istilah ekklesia berasal dari kata ek dan kaleo yang artinya memanggil keluar. ${ }^{2}$ Hal yang sama dijelaskan oleh Dieter Kuhl bahwa istilah gereja, berasal dari bahasa Yunani ekklesia yang berarti dipanggil keluar, yaitu orang-orang yang dipanggil keluar dari kegelapan kepada terang-Nya yang ajaib (1 Pet. 2:9) atau orang-orang yang telah berbalik dari kegelapan kepada terang, dan dari kuasa iblis kepada Allah (Kis. 26:18). ${ }^{3}$ Jadi Gereja merupakan persekutuan orang kudus, yaitu suatu persekutuan orang yang percaya dan disucikan di dalam Kristus serta disatukan dengan Dia sebagai Kepala. ${ }^{4}$

Dengan demikian Gereja berada di dalam rencana kekal Allah, karena Gereja merupakan orang yang dipilih sesuai dengan kehendak dan rencana Allah. Berkenaan dengan hal ini John Calvin memperkenalkan dua macam Gereja yaitu, Gereja yang kelihatan (visible-church) dan Gereja yang tak kelihatan (invisible-church). Gereja yang kelihatan adalah, Gereja yang dilihat secara organisasi, di mana Gereja itu memiliki anggota, gedung dan pengurus, misalnya Gereja GKI, GPIB dan lain-lain. Sedangkan Gereja yang tidak kelihatan lebih besar dari Gereja yang kelihatan, karena mencakup semua umat Allah di segala bangsa dan di segala waktu, termasuk yang sudah meninggal dan setiap orang yang percaya di masa yang akan datang.

Gereja yang kelihatan di dalamnya terdapat Gereja yang tidak kelihatan. Gereja yang kelihatan menggabungkan semua orang yang mengaku diri sebagai orang Kristen, sedangkan Gereja yang tidak kelihatan adalah Gereja yang merupakan totalitas dari seluruh orang-orang percaya yang sungguh-sungguh menjadi milik Kristus. $^{5}$

Gereja memiliki tanggung jawab yang sangat penting, yaitu pembinaan kepada seluruh warga jemaatnya. Jika Gereja melalaikan tanggung jawab ini, maka jangan menyesal jika iman anggota jemaat tidak mengalami pertumbuhan yang signifikan, dan menjadi mangsa empuk bagi "serigala-serigala ganan" di sekitarnya. Warga Gereja Dewasa, sangat membutuhkan pembinaan, karena merekalah yang akan

\footnotetext{
${ }^{1}$ Dieter Kuhl, Sejarah Gereja Jilid I, (Batu: YPPII Departemen Literatur, 1998), 40-41

${ }^{2}$ Louis Berkhof, Theologi Sistematika, (Jakarta: Lembaga Reformed Injili Indonesia, 1997), 6

${ }^{3}$ Dieter Kuhl, Sejarah ..., 40-41

${ }^{4}$ Louis Berkhof, Theologi ..., 23

${ }^{5}$ Stephen Tong, Kerajaan Allah Gereja dan Pelayanan, (Surabaya: Mementum, 2001), 33-35
} 
mengajarkan kebenaran-kebenaran Firman Tuhan kepada anak-anak mereka atau generasi muda di bawahnya, agar mewarisi iman dan keteladan para seniornya.

Dengan latar belakang masalah inilah, penulis tertarik untuk membahas Pembinaan Warga Gereja Dewasa menurut Surat Efesus 4:11-16.

\section{BAB I}

\section{GEREJA DI TENGAH SEKULARISME}

Gereja dipanggil dan ditugaskan untuk melaksanakan kehendak Tuhan, mencapai bangsa-bangsa dengan berita keselamatan. ${ }^{6}$ Tugas dalam pelayanan gereja adalah menjadikan gereja sebagai utusan Allah yang murni dalam melaksanakan tugas dan tanggung jawab pelayanan, baik melalui kerygma (mengajar atau memuridkan), marturia (bersaksi), koinonia (bersekutu), dan diakonia (pelayanan sosial).

Pada masa kini, gereja diperhadapkan dengan tantangan bahwa di balik keuntungan yang diperoleh melalui kemajuan modernisasi, ada dampak lain yang dialami pula, yaitu munculnya sekularisme, yang ternyata juga mengikis banyak sendi-sendi kehidupan beragama dan budaya tradisional. Herlianto menceritakan bagaimana kondisi gereja di Eropa yang mengalami masa Pasca Kristen (post cristianity), di mana masyarakat telah kehilangan sentuhan dan pengalaman rohani dalam kehidupan agama mereka. Survei yang dilakukan oleh Institut for Public Opinion Research di Allensbach, Jerman tahun 1987 menyebutkan ada 46\% penduduk Jerman yang mengatakan bahwa agama tidak diperlukan lagi, dan hanya $25 \%$ yang masih percaya bahwa agama memberi jawaban bagi kehidupan masa kini. Ada dua per tiga responden mengatakan bahwa mereka percaya kepada Tuhan, tetapi hanya sepertiga saja yang hidup berdasarkan ajaran Gereja, dan 57\% responden mengaku tidak pernah atau jarang ke gereja.

Di Inggris dan Belanda, sekularisasi dalam Gereja dapat terlihat melalui banyaknya kegiatan Gereja yang diisi dengan acara sekular, bahkan ada yang dijadikan restoran dan gedung pertunjukan/teater, dari khotbah-khotbah di gereja hanya berbicara masalah sosial politik tanpa ada kaitan apa-apa dengan kehidupan spiritual dan surgawi. Bahkan lebih diperparah lagi dengan banyaknya Pendeta yang kurang menyadari panggilan imannya sebagai Pendeta. Jabatan kependetaan tidak berbeda dengan status pegawai negeri yang hidup dan menunggu gaji bulanan. Kenyataan demikian menghasilkan kurangnya profesionalisme dalam pelayanan kependetaan, akibatnya motivasi melayani semakin merosot. Ironisnya para Pendeta muda yang umumnya berpredikat teolog, kehilangan motivasi untuk mengabarkan Injil. Tidak dapat dipungkiri bahwa, sekularisasi dan kurangnya motivasi Pendeta bukanlah kendala satu-satunya, sebab kemerosotan jemaat di Gereja-gereja tradisional dan mapan juga terjadi karena anggota jemaat banyak yang pindah

\footnotetext{
${ }^{6}$ Dieter Kuhl, Sejarah ...., 40
} 
mencari Gereja atau persekutuan yang lebih hidup, yaitu Gereja-gereja yang masih percaya bahwa Alkitab adalah Firman Allah, termasuk Gereja tradisional yang masih conservative, Gereja Injili dan Kharismatik. Tetapi banyak juga yang ber-exodus menjadi anggota sekte yang menyesatkan seperti Saksi Yehova dan Mormon, di mana mereka memperoleh persekutuan yang fanatik, dan sama sekali tidak mereka peroleh di Gereja-gereja besar yang diikuti semula.

Kondisi yang dialami Gereja di Eropa juga dialami di Indonesia. Dampak sekularisme sudah menjadi panutan banyak orang di mana pengaruh-pengaruh khususnya melalui film di bioskop dan acara di televisi, baik film berseri dari Barat maupun siaran iklan yang sangat dominan menuju sekularisme. Bahkan Gereja sudah terperangkap sekularisme, di mana nilai-nilai rohani dan Alkitab sudah ditinggalkan, dan digantikan dengan nilai-nilai sekular/duniawi. Ini umumnya menimpa Gerejagereja tradisional yang sudah mapan. Keanggotaan Gereja hanya bersifat tradisi dan kebiasaan. Kehidupan iman tidak berdampak sekali dalam kehidupan jemaat. Banyak anggota Gereja yang tidak lagi memperhatikan nilai-nilai spiritual. Aspek tradisional dan kerutinan begitu kuat mengakibatkan orang tidak tahu lagi arti kehidupan bergereja, selain pada hari Minggu mereka melakukan kebiasaan kebaktian di Gereja. Sedangkan kegiatan-kegiatan misi seperti penginjilan sudah hilang dari kamus jemaat. Gejala-gejala kemerosotan yang lain, nampak karena adanya keluhan-keluhan dari Gereja, bahwa calon-calon Pendeta yang sedang praktek di Gerejanya sudah tidak lagi berperilaku layaknya Pendeta. Kantor-kantor Sinode Gereja juga banyak yang terkena polusi asap rokok, sekalipun para teolog tahu akan bahaya merokok bagi kesehatan. Mereka memaksa diri menjadi perokok hanya untuk menunjukkan bahwa dirinya modern, sehingga dengan perilaku yang demikian dapatlah dimengerti mengapa banyak anggota jemaat yang tidak puas dan ber-exodus dari Gerejanya. Jemaat membutuhkan panutan, bukan contoh yang sudah biasa dijumpai di luar Gereja.

\section{BAB II}

\section{PEMBINAAN WARGA GEREJA DEWASA}

Untuk menghadapi sekularisme dalam kehidupan Gereja, tidak lain harus lebih berpusatkan pada Injil anugerah, yang menjadikan Firman Allah yang kekal itu sebagai pedoman bagi ajaran maupun tingkah laku jemaat. Jika tidak, maka sekularisme, tradisional, dan kerutinan juga akan melanda Gereja-gereja di Indonesia, seperti yang telah terjadi di Eropa, khususnya di Inggris dan Belanda. Oleh karena itu sangat diperlukan pembinaan bagi warga Gereja dewasa.

Istilah pembinaan (Inggris: nurture), mempunyai arti, memberikan makan (to feed), memperkaya (to nourish), membesarkan (to bring up), melatih (to train) dan 
mendidik (to educate). ${ }^{7}$ Kata pembinaan menurut Kamus Besar Bahasa Indonesia yaitu proses, perbuatan, cara membina, pembangunan, pembaharuan, penyempurnaan, usaha, tindakan dan kegiatan yang dilakukan secara berdayaguna dan berhasil guna untuk memperoleh hasil yang lebih baik lagi. ${ }^{8}$ Pembinaan warga Gereja juga memiliki makna memperlengkapi angota-anggota Gereja sehingga mereka menjadi dewasa (Ef. 4:13) serta sanggup menunaikan tugas mereka sebagai garam dan terang, bukan hanya untuk melayani di dalam Gereja tetapi terutama di luar Gereja, karena justru merekalah Gereja yang terbesar di tengah-tengah masyarakat. ${ }^{9}$

Pada akhir abad ke-20, yang dikenal sebagai era globalisasi, Gereja mulai memikirkan dan proaktif menjawab berbagai tantangan dengan meningkatkan dan mengembangkan bentuk-bentuk pelayanan gerejani. ${ }^{10}$ Peranan Pembinaan Warga Gereja tidak hanya merupakan kebutuhan yang dirasakan oleh kalangan warga Gereja dewasa, tetapi juga di kalangan pemimpin Gereja, bahkan di semua kalangan dan lapisan masyarakat. ${ }^{11}$ Oleh sebab itu, baik warga Gereja maupun pemimpin Gereja perlu diperlengkapi. Memperlengkapi warga Gereja dewasa melalui pelaksanaan pembinaan merupakan suatu proses yang tidak mudah, karena yang menjadi objek pembinaan adalah orang dewasa. Berbicara tentang kedewasaan, Thatcher dan Mc Queen menuliskan bahwa, dewasa (adult) adalah a person grown to full size and strenght. ${ }^{12}$

Kedewasaan merupakan proses perkembangan ke arah kematangan (maturity). ${ }^{13}$ Pada hakekatnya manusia mengalami proses perkembangan, baik secara fisik maupun psikologi. Proses perkembangan psikologi orang dewasa memiliki tingkatan-tingkatan psikologis. Elizabeth Hurlock mengatakan bahwa: secara kronologis orang dewasa mencakup usia 20-60 tahun, dan usia tersebut terbagi dalam tiga tahap dengan ciri masing-masing, yaitu:

\section{Masa Dewasa Awal (20-40 tahun)}

Usia ini di mana seseorang memasuki dunia dengan kebutuhan dan tanggung jawab yang lebih luas. Dalam mengerjakan suatu pekerjaan, bantuan atau nasehat dari yang lebih tua usianya tidak diperlukan lagi. Dengan kata lain, kecenderungan yang muncul pada usia ini adalah keinginan untuk bebas, mandiri dan kreatif. Hal ini terjadi karena besarnya keinginan untuk menampakkan bahwa dirinya sudah mandiri atau dewasa, bukan lagi sebagai anak, atau remaja dan pemuda, serta memiliki

16

\footnotetext{
${ }^{7}$ Samuel Sidjabat, Pendewasaan Manusia Dewasa, (Bandung: Institut Alkitab Tiranus, 2000),
} 8 Kamus Besar Bahasa Indonesia, (Jakarta: Balai Pustaka, 1989), 117

${ }^{9}$ Institut Oikumene Indonesia, Pembinaan Warga Gereja Memasuki Masa Depan, (Jakarta: BPK Gunung Mulia, 1980), 16

${ }^{10}$ Samuel Sidjabat, Pendewasaan Manusia ..., 88

${ }^{11}$ Ibid.

${ }^{12}$ Virginia S. Thatcher \& Alexander McQueen, Educational Book of Essential Knowlledge an Edition of the Webster Encycloped Dictionary of the English Language, (American: Consolidated Book Publisher, 1969), 105

${ }^{13}$ Samuel Sidjabat, Pendewasaan ..., 36 
banyak potensi. ${ }^{14}$ Kebutuhan atau pergumulan usia dewasa awal adalah mencakup beberapa hal, di antaranya bahwa orang dewasa awal bergelut dalam pengaturan diri sendiri seperti dalam hal memilih dan menjalankan pekerjaan, mengembangkan jati diri atau kemandirian, mengembangkan relasi dengan teman sejenis dan lawan jenis, mencari pasangan ideal, memasuki pernikahan, dan seterusnya. Banyak waktu yang tersita untuk memikirkan dan membina pengembangan karier, sehingga urusan gereja seringkali menjadi kurang penting. ${ }^{15}$

Selain hal di atas, usia dewasa awal juga mengalami krisis psikologi dan sosiologis, di mana ada tiga kekuatan yang tarik menarik dari tiga kepentingan di mana masing-masing membutuhkan perhatian dan energi yaitu: di rumah (istri/suami dan anak-anak), di tempat kerja (atasan dan bawahan), di masyarakat (termasuk di gereja). Oleh sebab itu orang dewasa awal membutuhkan bimbingan dalam hal menjaga ketiga hal tersebut agar dapat berjalan secara kreatif dan dinamis. Melihat tugas dan pergumulan usia di dewasa awal, maka masalah pemilihan kerja yang tepat dan sesuai dengan kepribadian, juga strategi peningkatan karier berdasarkan nilainilai Injil, merupakan tema yang perlu diperbincangkan dalam kalangan usia ini. Begitu pula dengan pemilihan pasangan hidup, menjalani masa pacaran dan pertunangan, bahkan bagaimana menjadi pasangan yang ideal, bagaimana menjadi orang tua yang efektif, bagaimana membina dan mendisiplinkan anak, dan memahami anak, merupakan hal-hal yang menarik untuk didiskusikan.

Berkenaan dengan permasalahan dan kebutuhan yang dihadapi usia dewasa awal, maka materi yang digunakan adalah materi yang tentunya sesuai dengan kebutuhan atau persoalan yang mereka alami, baik secara pribadi, di dalam keluarga maupun di lingkungan gereja. Metode yang dimaksud mencakup:

(1) Pengembangan daya kritis dan kreatifitas serta idealisme yang sehat. Dengan memberikan pengajaran dan diskusi-diskusi, bagaimana memahami perubahan jaman secara kritis dan interpretative merupakan hal yang sangat tepat bagi orang dewasa awal, karena mereka ingin belajar. ${ }^{16}$

(2) Pembinaan selain dilakukan dalam bentuk pengajaran dan persekutuan, pendekatan informal pun diperlukan seperti dengan membentuk klub olah raga atas dasar minat.

(3) Melalui pendekatan terhadap kelompok yang sudah berkeluarga atau yang belum, serta kelompok profesi, untuk kemudian diberikan bimbingan tentang dasar nilai hidup, serta memberi bantuan supaya dapat berkembang dari sikap hidup egosentris mengarah kepada sikap mempedulikan orang lain. Sedangkan untuk masalah-masalah keluarga, pekerjaan, relasi dan keluarga, pembina dituntut berperan sebagai konselor. ${ }^{17}$

\footnotetext{
${ }^{14}$ Ibid., 64

${ }^{15}$ Ibid., 70

${ }^{16}$ Samuel Sidjabat, Pendewasaan Manusia ..., 72

${ }^{17}$ Ibid.
} 


\section{$\underline{\text { Masa Dewasa Setengah Baya/Menengah (40-60 tahun) }}$}

Berkenan dengan hal ini, Sidjabat menyatakan bahwa pembinaan warga dewasa setengah baya amat penting karena di usia ini memiliki posisi sebagai pemimpin di dalam keluarga, pekerjaan dan lingkungan masyarakat, serta budaya di mana aktif berkarya. Oleh karena itu, pada usia setengah baya ini berusaha terus untuk mendapatkan masukan iman, yang diharapkan sanggup memperbaharui pandangan hidup dan tata nilainya, sehingga dengan demikian dapat berfungsi sebagai "garam dan terang dunia" secara baik dan benar (Mat. 5:13-16). ${ }^{18}$

Usia ini juga berada pada periode ketakutan karena penurunan kekuatan fisik. Mereka lebih mudah dilanda stress karena perubahan jasmani (somatik), pengaruh atau tuntunan budaya (cultural), karena perubahan atau krisis ekonomi dan penderitaan oleh karena kehilangan orang-orang yang sangat dikasihi, misalnya istri, suami, anak, orang tua, atau kerabat lainnya. Oleh sebab itu pada usia ini pada umumnya bergumul dalam hal: penyesuaian diri dengan perubahan fisik, mental, pola pikir dari idealisme ke realisme. Pada umumnya juga senang mengurusi masalah adat-istiadat karena melihat dirinya sebagai "milik budaya.",19

Adapun pendekatan yang perlu diupayakan melalui pembinaan adalah perlunya sikap empati terhadap pergumulan yang dihadapi, memberikan kebebasan mengemukakan pendapat, pendekatan secara holistik serta keseimbangan antara teori dan praktek. Oleh sebab itu pengajaran yang dibutuhkan orang dewasa ini adalah mengenai problema nyata kehidupan, misalnya: masalah-masalah penderitaan, anugerah Allah dan pengharapan. Hal ini dapat direalisasikan melalui khotbahkhotbah dan ceramah yang diminati oleh golongan usia ini. ${ }^{20}$

\section{Masa Dewasa Lanjut (60 tahun ke atas)}

Usia dewasa lanjut tetap membutuhkan pembinaan, sama halnya pada usia tingkat yang lebih rendah. Untuk itu sangatlah perlu memahami pergumulanpergumulan di usia demikian. Pada umumnya usia lanjut ini akan mengalami perubahan-perubahan fisik berhubungan dengan fungsi panca indera (penglihatan, perasa, penciuman, pendengaran, dan perabaan) yang cenderung menurun dalam segi sensitivitas. Bahkan perubahan secara psikologis ditandai dengan lebih mudah mengalami depresi (tertekan), mudah curiga, dan mempertahankan diri atas pengalaman dan pendapat diri sendiri. Apabila dilihat dari aspek psikologi, maka usia lanjut lebih menonjolkan integritas (pengalaman pribadi yang lebih mapan), lebih berhati-hati, teliti, sabar serta bijaksana dalam melakukan tugas, sehingga dibutuhkan pertimbangan-pertimbangan yang matang untuk memberikan nasihat dan saran yang lebih baik.

Kesadaran menjadi model ini perlu diberitahukan, agar usia ini tidak merasa putus asa, melainkan merasa memiliki arti dan tujuan akan hidupnya di hadapan Allah. Oleh karena itu, bahan atau materi pengajaran di usia ini adalah pengajaran

\footnotetext{
${ }^{18}$ Samuel Sidjabat, Pendewasaan Manusia ..., 73

${ }^{19}$ Ibid., 74

${ }^{20}$ Ibid., 75
} 
tentang pengenalan akan Allah, termasuk jaminan hidup kekal yang diberikan Allah melalui Yesus Kristus, sehingga dapat menghadapi masa tua secara kreatif, serta bertanggung jawab terhadap gereja dan masyarakat. Sedangkan metode pembinaan yang baik untuk usia lanjut adalah melalui dialog, diskusi kelompok, dan rekreasi. Hal yang perlu diperhatikan dalam pembinaan di usia dewasa lanjut adalah mencakup pemenuhan layanan bagi kebutuhan fisik, psikologis, dan kesehatan. Kemudian secara psikologis berkenaan dengan perhatian, perkunjungan, sarana rekreasi melalui televisi dan sarana olah raga yang tepat.

Jadi, ketiga pemaparan penulis tentang perkembangan orang dewasa ini, merupakan hal yang sangat penting untuk diketahui agar pembinaan dapat berjalan dengan efektif dan sesuai dengan tujuan yang ingin dicapai. Satu hal yang perlu diperhatikan adalah bahwa kedewasaan secara psikologi adalah sangat penting, tetapi tidak dapat menjadi suatu tolak ukur untuk seseorang dapat dikatakan sudah mencapai dewasa secara rohani. Akan tetapi apabila seseorang memiliki kedewasaan secara rohani maka kedewasaan moral, psikhologis maupun etis akan dapat terwujud.

\section{BAB III \\ PEMBINAAN WARGA GEREJA DEWASA MENURUT EFESUS 4:11-16}

Penulis surat Efesus adalah Paulus. Surat ini ditulis ketika banyak gereja telah didirikan dan setelah Paulus mempunyai kesempatan untuk merenungkan hakikat dari organisasi yang baru terbentuk. ${ }^{21}$ Tempat penulisan surat Efesus adalah Roma. Ada empat surat yang ditulis pada waktu dia dipenjarakan yakni: Surat Efesus, Surat Filipi, Surat Kolose dan Surat Filemon. Surat Efesus dialamatkan kepada orangorang kudus/percaya di Efesus (Ef. 1:1).

Kota Efesus merupakan kota Asia terbesar di Kekaisaran Romawi, yang sangat kaya, termasyur, berotoritas, dan penuh takhayul yang berlebihan, serta dosa yang menyolok. Selama kurang lebih tiga tahun kota Efesus menjadi pusat pelayanan Paulus yaitu pada perjalanan misi yang ke tiga (th 52-56) dan dikatakan bahwa pelayanan Paulus di sana sangat berhasil dalam memberitakan Injil (Kis. 19:10).

Dalam konteks dekat, Paulus menasihatkan supaya setiap jemaat yang telah dipanggil dalam pelayanan mempergunakan karunia-karunia dalam memperlengkapi satu dengan yang lain demi pembangunan Tubuh Kristus. Kemudian pada teks sesudahnya, Paulus memberi pengarahan praktis tentang kehidupan orang percaya sebagai manusia baru, supaya tidak hidup lagi sama seperti orang yang tidak mengenal Allah, karena jemaat telah mengenal dan menerima pengajaran tentang Kristus dan telah hidup dalam kasih Kristus. Efesus 4:11-16 berisi tentang nasihat Paulus mengenai bagaimana orang-orang yang telah dipanggil, harus hidup berpadanan dengan panggilan-Nya, melaksanakan tugas dan tanggung jawab sesuai dengan karunia yang Kristus berikan bagi pembangunan Tubuh Kristus, sampai

${ }^{21}$ Merrill C. Tenney, Survei Perjanjian Baru, (Malang: Gandum Mas, 2003), 393-394 
mencapai kedewasaan penuh yaitu kesatuan iman dan pengetahuan yang benar tentang Anak Allah, serta bertumbuh di dalam Kristus.

Pada ayat ini, kondisi jemaat Efesus dapat dikatakan sedang berada dalam masa peralihan kepada kedewasaan penuh, artinya bahwa memang benar mereka memiliki iman di dalam Tuhan Yesus dan kasih terhadap sesama orang kudus (1:15), tetapi hal ini dirasa perlu untuk diperdalam. Sementara itu jemaat mengalami ancaman, baik dari dalam maupun dari luar gereja, seperti ajaran-ajaran sesat yang berkembang dan berusaha menarik mereka dari jalan yang benar. Oleh sebab itu, Paulus mengingatkan lagi tanggung jawab para penilik/penatua-penatua jemaat untuk melaksanakan tugas dan tanggung jawabnya dalam menggembalakan jemaat Allah (Kis. 20:17-38).

Kemudian ayat 12-16, secara keseluruhan menjelaskan tentang bagaimana sebagai anggota Tubuh Kristus harus melaksanakan tugasnya yaitu memberitakan Injil. Paulus mengatakan bahwa sampai mencapai kedewasaan penuh, yaitu kesatuan iman. Kesatuan hanya dapat diperoleh melalui kasih Kristus. Dengan kata lain kesatuan dalam jemaat juga merupakan suatu anugerah yang Allah berikan.

\section{$\underline{\text { Eksegese Surat Efesus 4:11-16 }}$}

Pada bagian ini, penulis melakukan analisa eksegetis teks Efesus 4:11-16. Untuk memahami lebih dalam, maka teks ini akan dibahas dalam dua bagian besar sesuai dengan struktur teks Efesus 4:11-16.

\section{Wujud Pemberian Kasih Karunia Allah (4:11)}

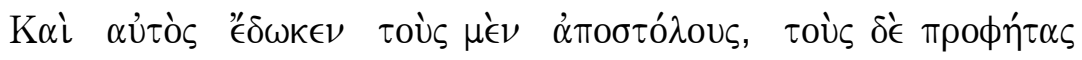

Adapun Ia mengangkat (menjadi) rasul-rasul yang lain sebagai nabi-nabi

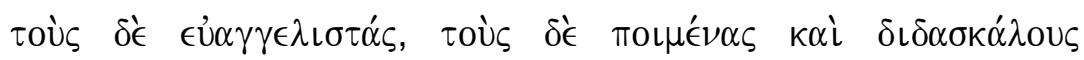

Yang lain pemberita Kabar Baik yang lain pemelihara2 dan pengajar-pengajar Jemaat

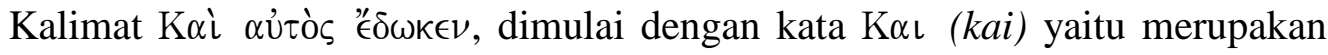
kata penghubung sederajat, yang berarti "dan, tetapi, juga, yaitu, baik .... maupun, bukan hanya, melainkan juga". Dalam ayat ini lebih tepat diterjemahkan "dan" sebagai sebuah penghubung yang menunjukkan bahwa ada kesinambungan antara

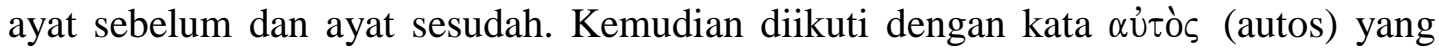
merupakan kata ganti berkasus nominatif (menyatakan subyek), maskulin, orang ketiga, tunggal, berarti "dia sendiri dan tidak ada orang yang lain." Hal ini menunjuk kepada Kristus sebagaimana yang sudah dijelaskan pada ayat-ayat sebelumnya, yaitu sebagai pribadi yang telah "memberikan atau mengadakan". Kata yang digunakan adalah " $€ \omega \kappa \epsilon \in v^{\prime}$ dari kata dasar $\delta\llcorner\delta \omega \mu \iota$ berarti "memberi, mempersembahkan, mengadakan, mengeluarkan, dan menyerahkan”. 
Jadi dalam terjemahan aslinya dapat diterjemahkan "dan Dia sendiri yang telah memberikan," dalam arti bahwa Paulus sebagai penulis ingin menegaskan bahwa apa yang Tuhan berikan itu semata-mata hanya karena kasih karunia-Nya, hal itu Ia lakukan berdasarkan kehendak dan kedaulatan-Nya. Ia memberikan sesuatu yang khusus, berarti Ia sendiri mempunyai maksud atau tujuan atas pemberian tersebut. Adapun wujud dari pemberian Allah adalah, rasul-rasul, nabi-nabi, pemberita-pemberita Injil, gembala-gembala dan pengajar-pengajar.

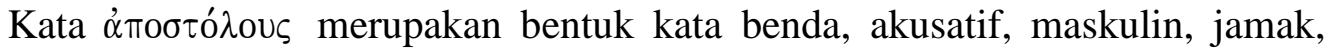

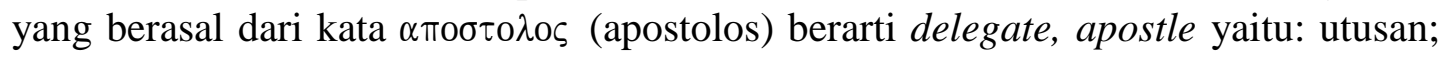
rasul. Jadi kata ini lebih tepat diterjemahkan rasul-rasul yaitu, seseorang yang diutus dengan otoritas Allah (yang diutus mewakili yang mengutus atau juga disebut representatif/wakil Allah. Kata ini mengandung makna pada pengutusan dengan suatu tugas tertentu.

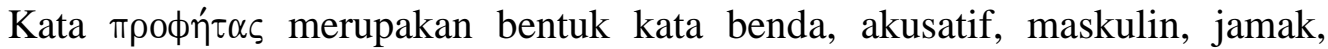

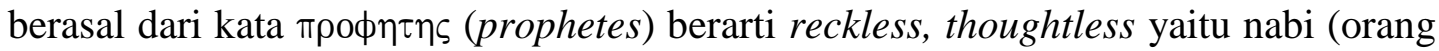
yang mengetahui kehendak Allah dan mempunyai karunia ucapan yang diilhami).

Kata $\epsilon \dot{\alpha} \alpha \gamma \gamma \in \lambda\llcorner\sigma \tau \alpha \dot{\varsigma}$ merupakan bentuk kata benda akusatif, maskulin, jamak, berasal dari kata $\epsilon \cup \alpha \gamma \gamma \lambda\llcorner\sigma \tau \eta \varsigma$ berarti proclamier yaitu pengabar Injil. Jadi, kata ini lebih tepat diterjemahkan pengabar-pengabar Injil, yaitu orang-orang yang secara khusus dipilih Allah untuk memberitakan Kabar Baik, atau biasa disebut Misionaris. Hal ini juga menunjuk kepada setiap orang percaya sebagai saksi Kristus yang menjalankan Amanat Agung di masa kini.

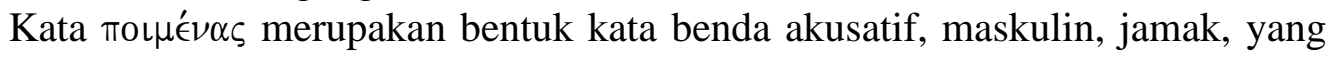

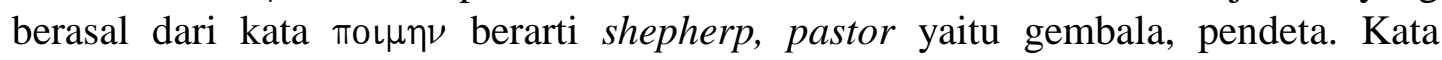
$\delta\llcorner\delta \alpha \sigma \kappa \alpha ́ \lambda$ o yang berarti teacher yaitu guru atau rabbi. Jadi terjemahan yang tepat untuk kedua kata ini adalah gembala-gembala (memelihara pertumbuhan rohani jemaat dan memobilisir karunia-karunia jemaatnya) dan pengajar-pengajar.

Semua yang tercatat di atas merupakapan wujud pemberian karunia Allah. Pemberian tersebut bukan untuk mempertentangkan antara karunia yang satu dengan yang, karena pemberian oleh Kristus untuk suatu maksud atau tujuan yang khusus.

\section{Maksud dan Tujuan Pemberian Allah (ayat 12-16)}

\section{$\underline{\text { Ayat } 12}$}

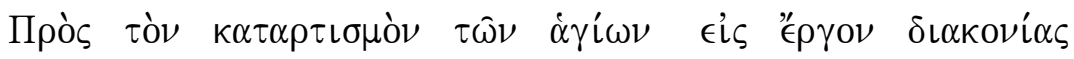

Untuk perlengkapan/melatih (orang-orang) kudus bagi perwujudan pelayanan

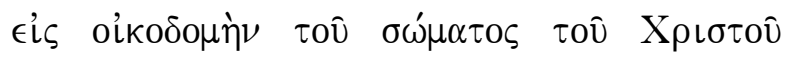

bagi pembinaan tubuh Kristus

\section{Ayat 13}

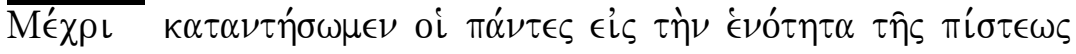

Sampai kita mencapai kesatuan iman

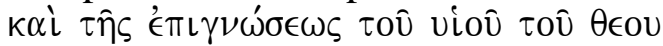


dan pengenalan (akan) Anak Allah

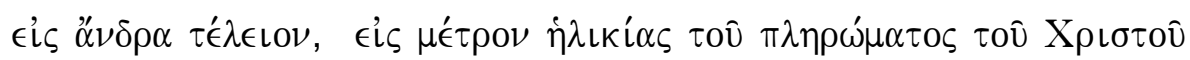

(menjadi) manusia dewasa dari kelimpahan Kristus

\section{$\underline{\text { Ayat } 14}$}

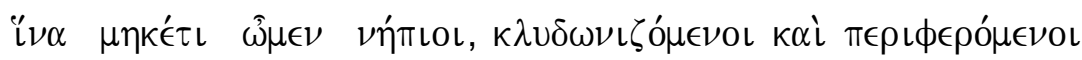

sehingga bukan lagi kita adalah anak2 (yang masih kecil) yang diombangambingkan (oleh ombak) dan dibawa kian kemari

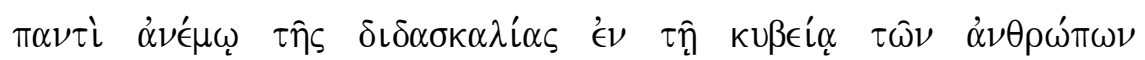

oleh setiap arus ajaran dengan kepandaian (penipuan) manusia-manusia

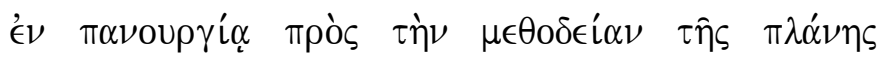

dengan kelicikan dengan tipu muslihat yang menyesatkan

\section{$\underline{\text { Ayat } 15}$}

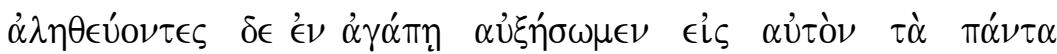
berpegang pada kebenaran, tetapi dalam kasih kita bertumbuh di dalam segala (hal) kepada Dia

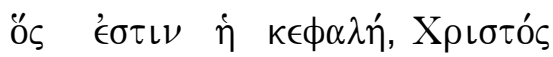

(yaitu) adalah Kepala, Kristus

\section{Ayat 16}

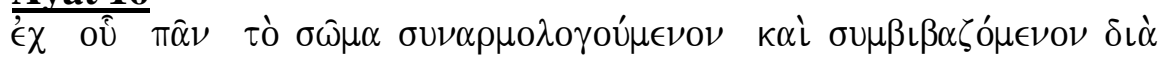
Dari-(Nya) seluruh tubuh disusun dengan rapi dan disatukan melalui

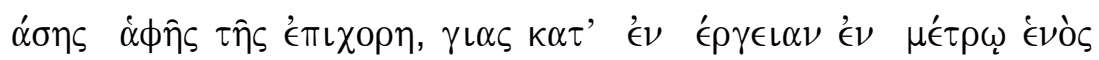
setiap sendi yang mendukung sesuai dengan fungsi dengan ukuran

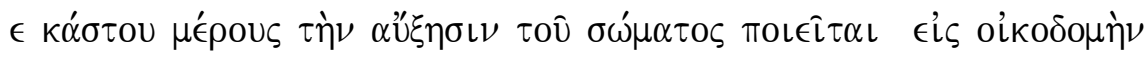
(tiap-tiap) bagian pembinaan tubuh membuat pembangunan

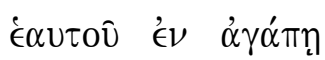

dirinya dalam kasih.

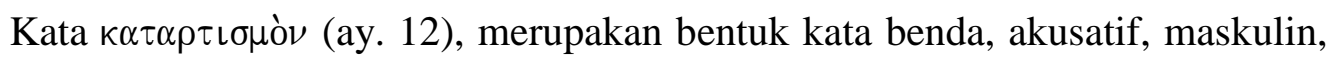

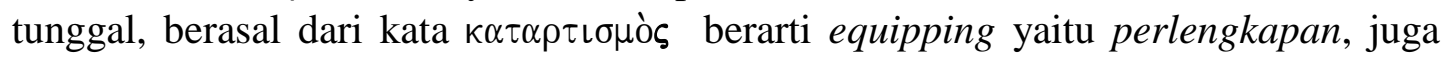
berarti prepare yaitu mempersiapkan, menyiapkan, menyediakan. Jadi terjemahan yang tepat untuk kata ini adalah "memperlengkapi".

Kata $\tau \omega \nu \alpha \gamma \iota \omega \nu$ yaitu kata sandang diikuti dengan kata sifat yang menunjuk kepada bentuk kata genetif, maskulin, jamak, berasal dari kata $\alpha \gamma \cos$ (hagios) yang berarti suci, kudus, umat Allah atau juga disebut God's people, holy, saint. Jadi 
terjemahan yang tepat orang-orang kudus yaitu dikuduskan atau disucikan oleh Allah.

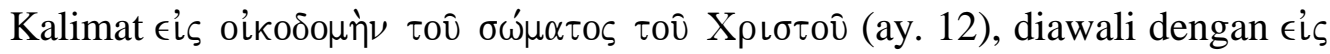
(kata depan) berbentuk akusatif berarti ke dalam, ke, kepada, pada, sampai, untuk, menjadi, di dalam, di, di tengah-tengah. Jadi kata $\epsilon i \varsigma$ lebih tepat diterjemahkan untuk.

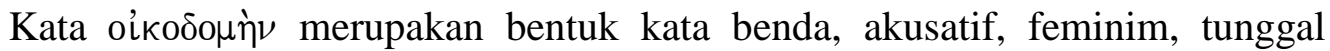

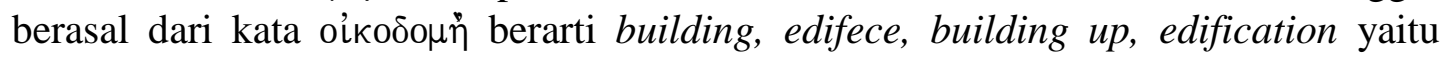
pembangunan, bangunan, gedung. Jadi terjemahan yang tepat adalah pembangunan.

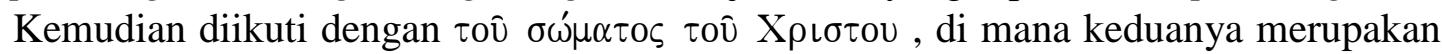
bentuk kata benda genetif, yaitu menyatakan milik. Kata $\sigma \omega ́ \mu \alpha \tau \varsigma^{\prime}$ merupakan bentuk kata benda, genetif, nauter, tunggal, berasal dari kata $\sigma \omega \dot{\mu} \mu \alpha$ artinya tubuh, badan jasmani, tubuh (Kristus), jemaat, gereja, kenyataan, wujud. Jadi terjemahan yang tepat adalah "tubuh". Paulus menuliskan bagian ini ditujukan kepada jemaat/gereja yang merupakan anggota Tubuh Kristus di mana Kristus disebut sebagai Kepala. Kedua-duanya berbentuk genetif, dengan maksud bahwa tubuh/jemaat itu adalah kepunyaan Kristus. Oleh sebab itu Paulus ingin menjelaskan bahwa jemaat itu adalah milik atau kepunyaan Kristus. Kristus menginginkan agar mereka diperlengkapi/disiapkan untuk suatu pekerjaan pelayanan milik Allah sendiri.

Kata $\mu \epsilon^{\prime} \chi \rho \iota$ (ay. 13) merupakan kata penghubung (antara induk kalimat dengan anak kalimat), yang bisa diartikan until (sampai). Kemudian, kata $\kappa \alpha \tau \alpha \nu \tau \eta ́ \sigma \omega \mu \epsilon \nu$ yang merupakan kata kerja subjungtif, aorist, aktif, orang pertama, jamak berasal dari kata $\kappa \alpha \tau \alpha \nu \tau \alpha \omega$ yang berarti reach, arrive at, come to other, to come to, to arrive at, to reach, to attain to, to come down to the goal. Jadi terjemahan yang tepat adalah sampai kita telah mencapai. Paulus ingin menekankan bahwa kegiatan memperlengkapi ini memiliki suatu tujuan/sasaran yang akan dicapai, yaitu kedewasaan penuh, kesatuan iman, dan pengetahuan yang benar tentang Yesus Kristus, serta kepenuhan di dalam Kristus.

Kata $\tau^{\prime} \in \lambda \in\llcorner O \nu$ merupakan bentuk kata sifat, akusatif, maskulin tunggal berasal dari kata $\tau \in \dot{\epsilon} \lambda \in \operatorname{lo} \varsigma$ berarti perfect, complete, adult, artinya sudah mencapi tujuan, lengkap, sempurna, utuh, genap, dewasa. Jadi terjemahan yang tepat adalah dewasa, yang merupakan goal/sasaran yang akan dicapai yaitu kesempurnaan, kedewasaan. Maksud Paulus bukan sekedar dewasa secara jasmani, karena ia mempertentangkannya dengan ayat 14 dengan sebutan anak-anak, tetapi yang Paulus maksudkan adalah dewasa di dalam iman, memiliki pengenalan yang benar akan Allah sehingga dimampukan untuk menghadapi tantangan-tantangan apapun yang dihadapi, dan dapat melayani Tuhan secara efektif bagi kemuliaan Allah yang empunya pelayanan tersebut.

Kata $\nu$ ท́ாடо (ay. 14), merupakan kata sifat, bentuk nominatif, maskulin, jamak berasal dari kata $\nu \eta \dot{\pi} \iota \varsigma \varsigma$ berarti childlike, naive yaitu anak kecil, bayi, balita, belum dewasa. Yang Paulus maksudkan adalah, supaya jemaat Efesus tidak bersifat seperti anak kecil/bayi yang menerima/memakan apa saja yang diberikan kepadanya, tidak krfitis dan selektif. Dalam hal ini tidak menerima pengajaran sesat yang sedang berkembang, karena jemaat sudah diperlengkapi/dipersiapkan serta memiliki pengetahuan yang benar tentang Kristus. 


\section{SIMPULAN}

Berdasarkan hasil analisa dan eksegese Surat Efesus 4:11-16 yaitu bahwa Kristus memperlengkapi orang-orang kudus dengan berbagai karunia adalah merupakan wujud dari pembinaan yang dilakukan-Nya sendiri. Keperbedaan karunia-karunia tersebut semuanya mengarah kepada pemberitaan Injil, sehingga Tubuh Kristus dapat bertumbuh mencapai kedewasaan penuh di dalam Kristus. Jemaat Efesus merupakan jemaat yang sudah percaya kepada Kristus, akan tetapi Kristus menginginkan agar keberadaan orang percaya yang telah diselamatkan itu dapat hidup berpadanan dengan panggilannya sebagai orang-orang yang telah dipanggil dan dikuduskan Allah. Oleh karena itu setiap gereja atau orang-orang yang telah dikuduskan Allah adalah anggota Tubuh Kristus, di mana Kristus sebagai Kepala. Tubuh membutuhkan suatu pertumbuhan agar mencapai kedewasaaan, sehinggga bukan lagi seperti anak-anak, akan tetapi bertumbuh menjadi dewasa, yaitu memiliki pengetahuan dan pengenalan yang benar akan Anak Allah, serta bertumbuh di dalam Kristus.

Adapun wujud pemberian Allah adalah rasul-rasul, nabi-nabi, pemberitapemberita Injil, gembala-gembala dan pengajar-pengajar, menunjuk kepada tugas yang Tuhan berikan kepada seorang anggota jemaat. Oleh karena itu seseorang yang memperoleh jabatan khusus itu, berarti bahwa ia dipilih Tuhan untuk suatu pekerjaan khusus dalam jemaat-Nya. Keberagaman karunia ini bukan untuk mempertentangkan antara karunia yang satu dengan yang lainnya, demikian pula bukan sesuatu yang harus dibangga-banggakan karena karunia-karunia tersebut tidak ada yang lebih tinggi/rendah, melainkan masing-masing diberikan oleh Kristus untuk suatu maksud atau tujuan yang khusus, memperlengkapi dan memberi sarana orang-orang percaya bagi pembangunan Tubuh Kristus, sehingga gereja dapat melaksanakan tugas dan tanggung jawabnya sebagai orang yang dipanggil Allah/rekan sekerja-Nya yaitu memberitakan Injil sesuai dengan karunia masing-masing.

Paulus sebagai rasul Kristus melakukan pembinaan bagi murid-muridnya, bahkan kepada seluruh jemaat di Efesus melalui berbagai macam cara/ metode pembinaan yaitu: melalui persekutuan-persekutuan, khotbah-khotbah, pengajaranpengajaran, nasihat-nasihat, doa, bahkan melalui sarana pendidikan. Hal ini dapat terlihat dari usaha Paulus dengan menyewa sebuah ruang kuliah dan setiap hari ia berbicara, penyampaian pengajaran-pengajaran tentang Kristus di ruang kuliah Tiranus (Kis. 19). Paulus memberikan pembinaan bagi setiap penatua, dan diaken yang ada di Efesus melalui doa dan nasihat-nasihat, agar melaksanakan tugas dan tanggung jawab yang Tuhan percayakan yaitu menggembalakan jemaat dengan melengkapi/ mempersiapkan orang-orang percaya lainnya (sebagai anggota Tubuh Kristus) untuk lebih produktif, yaitu siap melayani Tuhan dan aktif turut membangun Tubuh Kristus (Kis. 20).

Tugas panggilan gereja tidak pernah berubah. Tetapi bentuk-bentuk penerapannya tidak selalu sama dari tempat ke tempat, dan dari jaman ke jaman. Strategi pelayanan bagi orang dewasa disesuaikan dengan fungsi perkembangan, serta dengan isu penting di sekitar usia tersebut. ${ }^{22}$ Rancangan program pembinaan di jemaat harus disesuaikan dengan pergumulan individu maupun kelompok.

\footnotetext{
${ }^{22}$ Samuel Sidjabat, Pendewasaan ...., 39
} 


\section{DAFTAR PUSTAKA}

Berkhof, Louis

1997 Theologi Sistematika. Jakarta: Lembaga Reformed Injili Indonesia

Institut Oikumene Indonesia

1980 Pembinaan Warga Gereja Memasuki Masa Depan. Jakarta: BPK Gunung Mulia

Kuhl, Dieter

1998 Sejarah Gereja Jilid I. Batu: YPPII Departemen Literatur

Sidjabat, Samuel

2000 Pendewasaan Manusia Dewasa. Bandung: Institut Alkitab Tiranus

Tong, Stephen

2001 Kerajaan Allah Gereja dan Pelayanan. Surabaya: Mementum

Thatcher, Virginia S. \& Alexander McQueen

1969 Educational Book of Essential Knowlledge an Edition of the Webster Encycloped Dictionary of the English Language. American: Consolidated Book Publisher

Tenney, Merrill C.

2003 Survei Perjanjian Baru. Malang: Gandum Mas

1989 Kamus Besar Bahasa Indonesia. Jakarta: Balai Pustaka 